\title{
Metaphysical Anthropocentrism, Limitrophy, and Responsibility: An Explication of the Subject of Animal Rights
}

\section{J-H de Villiers*}

\section{P.E.R}

Pioneer in peer-reviewed, open access online law publications

Author

Jan-Harm de Villiers

Affiliation

University of South Africa

Email

dvillj@unisa.ac.za

Date of submission

11 July 2018

Date published

12 December 2018

Editor Prof C Rautenbach

How to cite this article

De Villiers J-H "Metaphysical

Anthropocentrism, Limitrophy, and Responsibility: An Explication of the Subject of Animal Rights" PER / PELJ 2018(21) - DOI

http://dx.doi.org/10.17159/1727-

3781/2018/v21i0a5320

Copyright

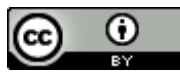

DOI

http://dx.doi.org/10.17159/17273781/2018/v21i0a5320

\begin{abstract}
This article undertakes a critical analysis of subjectivity and exposes the metaphysical and anthropocentric quasi-transcendental conditions that give rise to the construct(ion) of the Subject. I locate a critical moment for the metaphysical Subject in the work of Martin Heidegger which, whilst sadly not sustained in his later writings, provides a point of departure for an examination of the significance that animality plays in the metaphysical tradition and its constitutive relation to the construct of subjectivity. I discern this relation to be violent and sacrificial and draw on Jacques Derrida's nonanthropocentric ethics against the background of Drucilla Cornell's ethical reading of deconstruction to construct a critique of approaches that assimilate animals to the traditional model of subjectivity in order to represent their identity and interests in the legal paradigm. The main argument that I seek to advance is that such an approach paradoxically re-constructs the classical humanist subject of metaphysics and re-establishes the subject-centred system that silences the call of the animal Other, thereby solidifying and extending the legitimacy of a discourse and mode of social regulation that is fundamentally anthropocentric. I examine how we can address, incapacitate and move beyond this schemata of power through a rigorous deconstruction of the partitions that institute the Subject and how deconstruction clears a space for a de novo determination of the animal "subject" that can proceed from different sites of nonanthropocentric interruption. What follows is a call to refuse the mechanical utilisation of traditional legal constructs and I argue in favour of an approach to the question of the animal (in law) that identifies and challenges anthropocentrism as its critical target. I ultimately propose a critical engagement with the underlying metaphysical support of animal rights at a conceptual level, rather than simply utilising the law pragmatically as an instrument of immediate resolution.
\end{abstract}

\section{Keywords}

Animal rights theory; animal ethics; anthropocentrism; deconstruction; law and rights; limitrophy; metaphysics of subjectivity. 


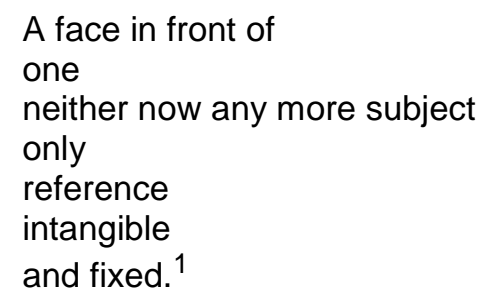

\section{Introduction}

Animal liberation theorists' engagement with the law has largely been a depthless and uncritical one. Relying on scientific accounts of animals to uncover and support claims about their moral standing and legal subjectivity, scholars have been turning to existing legal constructs and frameworks in an attempt to bring animals into the realm of legal consideration and protection. Rather than questioning the way in which the law (in its most general sense) continues to exercise anthropocentric power and silence the call of the animal Other, animal rights discourse labours under the unexamined supposition that existing legal constructs provide a suitable framework within which to effect changes in our thinking and relation with animals. There has, rather paradoxically, been little sustained engagement with the philosophicojuridical register of animal rights and a larger jurisprudential positioning of the animal in law and right(s). Whilst a plethora of moral and ethical philosophies on animal rights provides refined arguments in favour of the expansion or reformation of humanist liberatory discourse to ground the animal's moral and ethical agency, there has been a glaring neglect of engagement with the complexity of the subject, the being whose interests are to be protected through right(s). In short, the animal subject has been neglected in jurisprudence.

Whilst I am aware that there are multiple theoretical-philosophical approaches to animal rights theory and consequently don't wish to claim the existence of a single model, there are indeed recurring structural tenets that undergird the salient current models. ${ }^{2}$ Most notably for the purpose of my focus in this article, they all ultimately revert to a subject-centred model that functions at the junctures of highly problematic homogenising categorisations (human / animal, subject / object, owner / property, rational / irrational) that validate and sustain the anthropocentric and carno-phallogocentric

Jan-Harm de Villiers. BCom (Law) (cum laude) LLB (cum laude) LLM (Jurisprudence) (cum laude) (UP). Senior Lecturer, Department of Jurisprudence, University of South Africa. E-mail: dvillj@unisa.ac.za.

Poem by Friedrich Rolf Huber quoted in Cornell Philosophy of the Limit 142.

See Regan Case for Animal Rights; Regan Defending Animal Rights; Wise Drawing the Line; Francione Animals as Persons. 
metaphysical structure from which the very notion of subjectivity not only emanates, but upon which it is reliant.

The main purpose of this article is to (re)turn the discourse of animal rights to its dependency on the event of subjectivity through a modest and focussed engagement with the most fundamental pre-condition of rights: the question of the Subject. What follows is a call to refuse the mechanical utilisation of traditional legal constructs and to argue in favour of an approach to the question of the animal (in law) that identifies and challenges anthropocentrism as its critical target. It is a call to engage with the underlying metaphysical support of animal rights at a conceptual level, rather than simply to utilise the law pragmatically as an instrument of immediate resolution. I am thus reiterating a previous call for a critical approach of slowness. ${ }^{3}$ Animal rights theorists' eagerness to simply add animals into existing legal frameworks in the hope of effecting immediate change is understandable, given the almost unimaginable suffering that millions of animals endure every day. My project, however, stems from the premise that animal liberation will, unfortunately, inevitably be a slow and gradual process. Any approach that fails to take on the laborious, time-consuming task of confronting metaphysical anthropocentrism will foreclose the possibility of destabilising and moving beyond the very interpretation of the human (as subject) that lies at the heart of animal subjugation.

This article can roughly be divided into two parts, and unfolds as follows: In the first part I undertake a critical philosophical analysis of the subjectivity that undergirds rights, specifically focussing on the metaphysics of subjectivity and presence. I argue that the construct of subjectivity inevitably requires that the animal be assimilated to the prototypical and ground symbolic of the (hu)man of rights, ultimately reinforcing the containment of the animal in an identification as sub-human Other. In the second part of the article I examine how deconstruction clears a space for a re-conceptualisation of the animal "subject" in terms of subjection, substitution, hostage, and ultimately responsibility. I draw on Derrida's deconstructive gestures against the background of a previous engagement with Cornell's reconceptualisation of deconstruction to illustrate that deconstruction exposes a limit, in turn preserving the possibility of another thought of relation and ultimately another law. As such, I regard a deconstructive approach as vital to unweaving the anthropocentrism woven into the fabric of legal constructs and holding open the possibility of a post-subjective space that is non-anthropocentric. 


\section{The anthropomorphic hegemony of subjectivity}

Animal rights theorists effectively seek a displacement of the line that separates the (legal) subject from the (legal) object so that animals can be endowed with the substratum of (legal) subjectivity from which rights and correlative legal protection flow. Legal rights are internally linked with the metaphysics of subjectivity in its chronological conception and complementarity; rights are the legal validation of the metaphysics of subjectivity. ${ }^{4}$ Metaphysics - meta (over or beyond) ta physica (the physical material world) - is the study of that which lies beyond the immediate physical realm. Metaphysics aims to describe and make sense of the disorder that unknowables (like existence and possibility) confront us with, and to master finitude, which, as Heidegger ${ }^{5}$ remarks, "is not some property that is merely attached to us, but is our fundamental way of being".

We find the foundation of metaphysics in the classical Greek philosophers' reversal between the sensible and the intelligible, reaching its completion in Plato; the phenomenal world reflected as shadows against the dim wall of the cave and true reality existing in the sunlit world of ideas and forms. Beyond chaotic nature, which abounds with phenomena and appearances, lies the truth, which can be approached through philosophical dispositions of reason or logos. ${ }^{6}$ For Heidegger, ${ }^{7}$ the origin of metaphysics overlaps with the establishment of a certain humanism in which the human "move[s] into a central place among beings". Here human beings are defined, within a metaphysically established system of beings, as animal rationale and lead "to the liberation of their possibilities, to the certitude of their destiny, and to the securing of their 'life'". 8

Heidegger ${ }^{9}$ finds in Plato's thinking "a change that becomes the history of metaphysics". For Heidegger, Plato relinquishes the essence of "unhiddenness" and initiates a shift in the essence of truth. No longer is truth understood as the unhiddenness or unconcealment of beings themselves, but unhiddenness becomes "harnessed in a relation to looking, apprehending, thinking, and asserting". ${ }^{10}$ Truth is sequentially re-located in the correct narration and depiction of "objects" by the human "subject". If this understanding of truth finds its genesis in Plato, we see it reach its grand

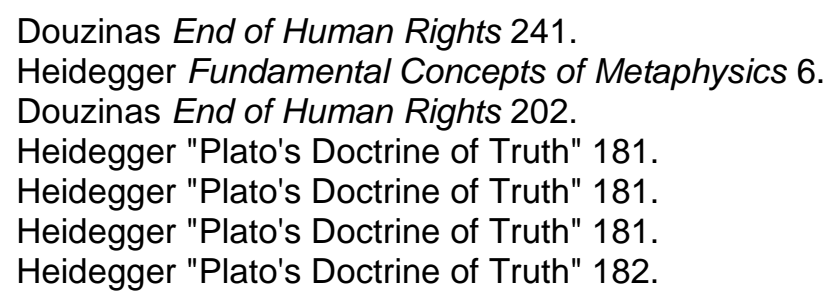


finale in Decartes' search for a fundamentum absolutum inconcussum veritatis - an absolute, unshakeable foundation of truth - which he locates in the self-present human subject. ${ }^{11}$

The word subject stems from the Latin subjectum, literally meaning "that which is thrown under". The subject thus designates a fundamental stratum for the affirmation of qualities, predicates and attributes. The Latin subjectum was translated from the Greek hupokeimenon, "that which lies under", a term that Aristotle used to refer to "that of which all other entities are predicated but which is itself not predicated of anything else". ${ }^{2}$ Hupokeimenon ascribes a foundation upon which all entities become intelligible, and a determination of the subject as hupokeimenon is a claim to the meaning of Being - defined as the foundation upon which entities are grasped as such. Heidegger pointed out that every conceptualisation of the subject, irrespective of its affirming substantialisation, continuously postulates an ultimum subjectum or absolute foundation, rendering any determination of subjectivity fundamentally metaphysical. ${ }^{13}$ Decartes' cogito ergo sum placed this foundation on humanity and, according to Heidegger, decisively turned classical metaphysics into anthropology by identifying the subjectum with the human subject, the final point of reference and ultimate ground of all that exists. ${ }^{14}$ Nietzsche punctuated and solidified the infection of rationality. For Heidegger, Nietzsche's inversing figuration of the human as animal rationale simply reinforces the metaphysical framework within which human subjectivity is constructed. Rather than moving beyond a metaphysical determination of the subject, Heidegger argues that Nietzsche's thought remains grounded in a subjectivist understanding of values and his reprioritisation of man's animality (over rationality) merely signals an inversion of the classical metaphysical definition and, with that, the closure of the metaphysical tradition's potentiality. ${ }^{15}$ At this closure, where "the Being of being human is exclusively presented in terms of the conscious subject, who sets the world forth and understands it through reduction of being to (self)representation", we find the human as the relational centre of all that is. ${ }^{16}$

Heidegger understood that metaphysics has ab initio been concerned with one guiding question, namely what is an entity (in its Being)? Critchley ${ }^{17}$ notes

\author{
Calarco 2004 Cont Philos Rev 178. \\ Critchley Ethics, Politics, Subjectivity 51. \\ Critchley Ethics, Politics, Subjectivity 52. \\ Douzinas End of Human Rights 204. \\ Calarco Zoographies 32. \\ Douzinas End of Human Rights 205. \\ Critchley Ethics, Politics, Subjectivity 52.
}


that metaphysics is not a regional ontology that asks after the Being of a region of entities like living things (biology) or physical matter (physics), but rather concerns itself with the question of the Being of an entity as such. The question of Being (or Seinsfrage) is thus the guiding question of philosophy for Heidegger and the philosophical tradition stretching from Plato to Nietzsche involves the unfolding of theses on the meaning of Being that progressively obfuscate its original sending. ${ }^{18}$ Metaphysics has thus always been a metaphysics of the subject to the extent that philosophy has always sought to designate the subjectum, the ultimate foundation from which entities become intelligible. In this sense, all the master words of pre-modern metaphysics (eidos, ousia, causa sui) are subjects and the subject is also always the subject of metaphysics. ${ }^{19}$

For Heidegger, the metaphysical tradition is guilty of a forgetfulness or oblivion of Being. This forgetfulness is embodied in a failure to ask the question of Being (in itself) and a synchronal development and determination of a concept of subjectivity. As explained above, the history of philosophy can be seen as a meditation on the subjectum as foundation for an understanding of entities and what is at stake in this tradition, for Heidegger, is a displacement of this metaphysical foundation. No longer residing in a form, substance or deity, the foundation is ultimately found in the human understood as subject. ${ }^{20}$ He writes:

The Meditationes de prima philosophia provide the pattern for the ontology of the subiectum constructed from the perspective of a subjectivity defined as conscientia. Man has become the subiectum. He can, therefore, determine and realize the essence of subjectivity - always according to how he conceives and wills himself. ${ }^{21}$

Heidegger ultimately forces us to reflect on the significance of the metaphysical baggage accompanying the unfolding conceptualisation and concluding identification of man as subject. I would like to further problematise this schema by approaching it from an interdependent, but differentiated vantage point, shifting the focus from the implications of the human becoming subject, to the significance of the human becoming subject. Recalling Critchley's assertion that metaphysics is concerned with the question of the Being of an entity as such, to what extent, if at all, is the metaphysical tradition concerned with the particular question of the animal's

18 Critchley Ethics, Politics, Subjectivity 52.

19 Critchley Ethics, Politics, Subjectivity 53.

20 Critchley Ethics, Politics, Subjectivity 53.

$21 \quad$ Heidegger "Age of the World Picture" 84. 
Being? What significance does animality play in the metaphysical tradition and in what relation does it stand to the construct of subjectivity?

By recognising that human(ity) was consistently juxtaposed to animal(ity) throughout the development of Western metaphysics - from Plato's ${ }^{22}$ view of humans as creatures "different and more divine, pastur[ing] other kinds of living creatures more lowly than themselves", to Aristotle's ${ }^{23}$ acquiescent sentiment that animals are inferior beings that "should be under subjection to man..." and Decartes' 24 well-known account of animals as automata or "machine[s] made by the hands of God" - we can begin to reflect on the anthropomorphic hegemony of subjectivity and its implications for discourses and institutions that evoke this construct. My aim is to illustrate that the construct(ion) of subjectivity is a violent, exclusionary process of othering. It is important to note that not only animals occupy a space of marginalisation within the metaphysical tradition, as classical concepts of subjectivity have excluded a plethora of Others. The earlier citation from Aristotle that I suspended with an ellipse highlights another dimension to the conjunctive sacrificial structure of the metaphysical tradition:

$\ldots$ so is it naturally with the male and the female, the one is superior, the other
inferior; the one governs, the other is governed... Those men therefore who are
as much inferior to others as the body is to the soul, are to be thus disposed of,
as the proper use of them is their bodies, in which their excellence consists. ${ }^{25}$

Aristotle's justification for the appropriation and ingestion of the juxtaposed Other's body has profound significance for the structure of subjectivity, and I will return to this argument below. The point that I am trying to make here, which is not unrelated to the main argument being developed, is that the subject has been constituted through various relations of hierarchy, each reflecting a particular form of power. Any challenge to these hegemonic constructs requires a radical re-thinking of the subject so as to avoid the paradox of challenging a form of power whilst accepting its own terms of reference. I am in particular concerned with anthropocentrism as a guiding thread of the metaphysical tradition and its implications for an attempt to assimilate animals to the existing model of legal subjectivity. If, as Heidegger has extensively argued, the metaphysical tradition has failed to adequately attend to the question of Being and the essence of the human is lost in the process of man's being conceived of as subject, what would the implications

\footnotetext{
$22 \quad$ Plato "Statesman" 313.

23 Aristotle "Treatise on Government" 17.

24 Descartes "Discourse" 44.

25 Aristotle "Treatise on Government" 17.
} 
be if the philosophical and legal concept of subjectivity were applied to other animals?

Heidegger's writings, specifically his early work, reflect a certain appreciation and consideration of the salience of metaphysical anthropocentrism. Despite his failure to sustain his early challenge to ontotheological anthropocentrism, Heidegger's reflections on the being of animal life nevertheless mark an important critical moment for the metaphysical subject, and the lines of inquiry opened up by his work provide a suitable point of departure for an engagement with the pervasiveness of metaphysical anthropocentrism.

\section{Heidegger and metaphysical anthropocentrism}

Heidegger's ${ }^{26}$ first seminal work, published in 1927, provides no more than brief fragmented references to the animal. Yet the question of animal Being, though neither pursued nor explicitly contextualised, lingers as a faceless subtext. Heidegger ${ }^{27}$ calls for a reciprocal relationship between philosophy and the positive sciences, arguing that an ontological foundation can assist science by "leap[ing] ahead into some area of Being, disclos[ing] it for the first time in the constitution of its Being, and, after thus arriving at the structures within it, mak[ing] these available to the positive sciences as transparent assignments for their inquiry". With this, Heidegger acknowledges the need for projects that determine Being beyond Dasein. Later in this text Heidegger $^{28}$ articulates a concern with beings as a whole and calls for a project on life, which would logically once again include other animals, as "a kind of Being in its own right". However, he immediately qualifies and positions the project of developing such an ontology of life as accessible only in Dasein and as a site of lack to be interpreted against the absence of qualities that differentiate Dasein's distinct Being. Heidegger insists on a privative interpretation and rejects an ontological definition of Dasein as "life... plus something else".29 This ground for analysis exposes more than a delineation of the entry point or scope of Heidegger's project at that specific time; it divulges a subtle yet pervasive anthropocentrism that would guide all his future writings, often in dissonance with his explicit opposition to certain anthropocentric leitmotifs of the metaphysical tradition that shape and legitimise the humanism that he finds so problematic.

Heidegger Being and Time.

Heidegger Being and Time 30-31.

Heidegger Being and Time 75.

Heidegger Being and Time 75. 
The essence of the animal and her specific manner of being enjoy significantly more attention in his lecture course ${ }^{30}$ delivered shortly thereafter in 1929, and whilst the question of the human/animal distinction is addressed (to varying degrees) in several of his writings, ${ }^{31}$ Heidegger's most sustained engagement with an ontology of animal life is to be found in this text. Here his thesis on the reciprocity between philosophy and science is once again emphasised, complicated and refined, inter alia through an engagement with the relationship between Zoology and the philosophical project of determining the animal's essence. His interpretation, Heidegger holds, is valid for the relationship between philosophy and all the sciences and it elucidates an association of communal cooperation and reciprocal enlightening. Heidegger ${ }^{32}$ calls the relation between metaphysics and the positive sciences "an ambiguous one" and I read this characterisation as a problematisation of the tendency in both philosophy and the sciences to claim absolute autonomy over certain processes and objects of inquiry, a tendency that renders both isolated disciplines wanting. Addressing "the magnitude of difficulties surrounding a metaphysical interpretation of life" requires a twofold discursive shift: a repositioning of philosophy seen as a purely transcendental discourse capable of determining the essence of an entity without recourse to biological science and, concomitantly, of science seen as a positivistic uncovering of "facts" without any need for interpretation or ontology. It is through an engagement with the phenomenon of "world" that Heidegger aims to initiate this reciprocal relation and distinguish human Dasein from other animals by exposing their respective modes of Being. ${ }^{33}$

\subsection{Heidegger and the question of world}

Heidegger's engagement with the question of world starts with the supposition that humans are not merely part of the world, but moreover have world. But what about other beings that are also part of the world, like the animal, plant and stone? Heidegger ${ }^{34}$ proposes that certain distinctions immediately manifest themselves, "however crudely", upon undertaking a comparative examination:

30 Heidegger Fundamental Concepts of Metaphysics.

31 See inter alia Heidegger Being and Time; Heidegger What is Called Thinking?; Heidegger On the Way to Language; Heidegger "Origin of the Work of Art"; Heidegger Parmenides; Heidegger "Letter on 'Humanism'".

32 Heidegger Fundamental Concepts of Metaphysics 188.

33 Lewis 2017 Cosmos and History 52-53.

$34 \quad$ Heidegger Fundamental Concepts of Metaphysics 177. 
[1.] The stone (material object) is worldless; [2.] the animal is poor in world; [3.] man is world-forming.

In explaining his thesis that the animal is poor in world whilst man is worldforming, Heidegger ${ }^{35}$ insists that this comparison "allows no evaluative ranking" and that it is not founded in the questionable habitual assessment that man has a higher or greater completeness of experiences and accessibility than animals. For Heidegger, anthropocentric hierarchical evaluations of essence and capacities are not only problematic in their denial of the complexities of animal relations (considering, for example, how the falcon's sense of sight and the canine's sense of smell surpass that of the human), such evaluations furthermore preclude an appreciation of the specificity of animals' world relations with other beings and are grounded in the very problematic premise that we can indeed compare human and animal world relations through the variegation of collective (dis)similarities.

It is in Heidegger's commitment to a thinking of animality on the animals' own terms that we find his most progressive digression from the metaphysical tradition that he extensively critiqued. Heidegger's ${ }^{36}$ assertion that the determination of the animal's world relations "cannot be decided by reflections on language but only by taking a look at animality itself" signals a radical withdrawal from the anthropocentric prism through which the animal has traditionally been approached in Western philosophy. It is, however, also at this very juncture of trying to distinguish between the human and animal relation to world that Heidegger reasserts some of the most dogmatic and problematic tenets of traditional metaphysical discourse. ${ }^{37}$

It needs to be noted that Heidegger's entire engagement with animality is aimed at articulating the unique relational structure of human Dasein and that his analysis of the animal's world-lessness serves to demarcate, through contrast and comparison, the essence of man's world-forming capacity. ${ }^{38}$ "World" here designates for Heidegger a relational realm in which entities or beings are reciprocally present and accessible. The stone has no world; it does not "touch" the earth in any proper sense but merely "crops up" wherever it falls, having no relational force or access to the world in which it finds itself. ${ }^{39}$ The animal, by contrast, does have a relational structure and access of some kind. The lizard basking in the sun has not just cropped up in the world. When removed from the rock on which she is lying, the lizard

\footnotetext{
$35 \quad$ Heidegger Fundamental Concepts of Metaphysics 194.

36 Heidegger Fundamental Concepts of Metaphysics 195, own emphasis.

37 Calarco Zoographies 22-23.

$38 \quad$ Calarco "Heidegger's Zoontology" 20.

$39 \quad$ Heidegger Fundamental Concepts of Metaphysics 197.
} 
will start looking for her stone again, as she is accustomed to doing. The crucial point of differentiation, however, is that the lizard has no mode of being that allows her to penetrate the Being of an entity; to relate to the rock as a rock, or the sun as the sun. It is the lack of this relational "as" structure that, for Heidegger ${ }^{40}$ renders the animal poor in world and precludes a capacity for ek-sisting:

The manifestness of beings as such, of beings as beings, belongs to world. This implies that bound up with world is the enigmatic 'as,' beings as such, or formulated in a formal way: 'something as something,' a possibility which is quite fundamentally closed to the animal.

For Heidegger, ${ }^{41}$ Ek-sistenz is thus inextricably linked to the dis-closive aptitude of Dasein; his specific way of relating to himself, others, and "mere possibility as Idea". Heidegger ${ }^{42}$ denotes (such) ek-sistence as "standing in the clearing of being", adding "this way of being is proper only to the human being". Heidegger's conceptualisation of "world" thus ultimately assumes (or perhaps rather subsumes) the ability to ek-sist. ${ }^{43}$ It is pertinent to reflect on the relevance of Heidegger's insistence that only man ek-sists, for it is a point that he repeatedly accentuates. Whilst it is clear that Heidegger is advancing the thesis that the metaphysical tradition has always been forgetful of Being and ignored what he deems to be man's essence, Heidegger is also solidifying a disconnection between animalitas and humanitas. Here it is important to recall Heidegger's rigorous critique of Nietzsche's thinking as the fulfilment and closure of the Western metaphysical tradition.

I share the view that Heidegger not only fails to see the critical promise of Nietzsche's ontology, but that his critique furthermore exposes the very blind spot in his own thinking that encloses his project within the confines of metaphysical thought. ${ }^{44}$ Heidegger's critique is articulated against his view of the history and culmination of metaphysics as the subjectivisation of Being. What Heidegger failed to account for, however, is that the history of modern metaphysics is the progressive subjectivisation of (the) human-Being. For all

$40 \quad$ Heidegger Fundamental Concepts of Metaphysics 274.

$41 \quad$ Heidegger "Letter on 'Humanism'" 249.

42 Heidegger "Letter on 'Humanism'" 247.

43 This conceptualisation entrenches the essential gulf or "abyss" that, for Heidegger, separates humans and animals. He states "in any case living creatures are as they are without standing outside their being as such and within the truth of being, preserving in such standing the essential nature of their being. Of all the beings that are, presumably the most difficult to think about are living creatures, because on the one hand they are in a certain way most closely akin to us, and on the other they are at the same time separated from our ek-sistent essence by an abyss". Heidegger "Letter on 'Humanism'" 248.

For an extensive explication of this position, see Calarco Zoographies 31-43. 
Heidegger's efforts to uncover the essence of Dasein through a clear delineation and demarcation of the chasm that separates man from animal, it is the concretisation, implementation and perpetuation of this metaphysicoanthropocentric axiomatic that frustrates and ultimately obstructs the possibility of moving beyond the metaphysics of subjectivity. Just as the tradition that preceded him, Heidegger's engagement with animals and animality serves to develop an understanding of the human's specificity and essence, and not as beings to be considered in their own right or on their own terms. This is not merely an inescapable modus that accompanies an inquiry that takes the human being as focal point; Heidegger is at pains to conceptualise man's separateness in opposition to the threat that the animal poses to that particularity. ${ }^{45}$ Heidegger's ${ }^{46}$ critique of the metaphysical humanism that "does not set the humanitas of the human being high enough" is thus deeply rooted in an essentialist logic of opposition between human and animal, and his project of displacing the metaphysical interpretation of man ultimately leaves us with a more rigorous delimitation of man that is grounded in highly problematic oppositions that remain inadequately questioned. Derrida's ${ }^{47}$ assertion that Heidegger's discourse "disrupt[s]... a certain traditional humanism" whilst ultimately remaining a "profound humanism" should be read from this perspective.

\section{Thinking at the limit of the subject}

If Heidegger's Dasein comes before the (dedomiciling of entities into object and) subject, who or what comes after the subject? In order to elucidate what is at stake in the contestation of this limit, I (re)turn to Nancy's interview with Derrida on the notion of subjectivity that I have previously engaged with. ${ }^{48}$ Responding to Nancy's question "Who comes after the subject?" Derrida immediately delineates two concerns with Nancy's formulation. The first is intended as a response to prevailing criticisms or doxa on the "simple liquidation" of the subject and the second as a reproach to the unquestioned anthropocentrism that continues to emblematise the post-humanist tradition.

Derrida firstly argues, contra popular neo-humanist notions, that the discourses of Lacan, Althusser, Foucault, Freud, Marx and Nietzsche present a questioning, re-interpretation and re-positioning of the subject in its historico-cultural complexity. Far from "liquidating" the subject, the radically

\footnotetext{
$45 \quad$ Calarco Zoographies 53.

$46 \quad$ Heidegger "Letter on 'Humanism'" 251.

47 Derrida and Nancy "'Eating Well'" 113.

48 De Villiers 2012 SAJHR.
} 
decentered subject invites reflection on the consequences of such displacements for various institutions. The call for a "return to the subject" is thus confused in its misunderstanding of the constitution of the subject, as if there is indeed a Subject to return to. "There has never been The Subject for anyone", reminds Derrida. ${ }^{49}$ "The subject is a fable... but to concentrate on the elements of speech and conventional fiction that such a fable presupposes is not to stop taking it seriously (it is the serious itself)". 50 There is no authorial-authoritarian subject that is not confronted with a certain disruption or différance at its core. The condition of deconstruction is thus not an extraneous thematic that is being imposed on the thinkers of subjectivity, but a fundamental force at work in the authorial functions of the subject. ${ }^{51}$ Once the subject has been "re-interpreted, displaced, decentered, reinscribed", the challenge for thought is firstly to work through the implications for institutions that presuppose the subjectum in its Cartesian and postCartesian forms, and secondly to attend to the determination of the who or what responding to the question "who" (comes after the subject)? ${ }^{52}$ The latter point, against which Derrida raises his second apprehension, informs my central concern.

Derrida is careful to keep a critical distance from post-humanist theorists who sustain and reproduce an unquestioned anthropocentrism. For Nancy, ${ }^{53}$ the "who" designates a locus post-subjectivity, "that place 'of the subject' that appears precisely through deconstruction itself" and he elaborates by asking, "What is the place that Dasein, for example, comes to occupy?" Derrida ${ }^{54}$ remains highly sceptical of a simple overcoming of the metaphysical closure, warning that the substitution of "a very indeterminate 'who' for a 'subject' overburdened by metaphysical determinations" is not likely to result in a decisive displacement, and Heidegger's all too human Dasein remains, for Derrida, enclosed in the occlusion of metaphysical humanism and anthropocentrism. Derrida ${ }^{55}$ is especially critical of the remnants of selfpresence implicit in Dasein's phenomenological (as such) relational mode and its function of radically and rigorously separating Dasein from other animals. The analytic of Dasein invokes conceptual oppositions that have not been adequately interrogated and the critical project of addressing and moving beyond the metaphysical problematic of the subject is located at the

\footnotetext{
Derrida and Nancy "'Eating Well"' 102.

Derrida and Nancy "'Eating Well'" 102.

Calarco 2004 Cont Philos Rev 186.

Derrida and Nancy "'Eating Well'" 98.

Derrida and Nancy "'Eating Well'" 98.

Derrida and Nancy "'Eating Well'" 100.

Derrida and Nancy "'Eating Well"' 105.
} 
borders of these oppositions. Here we find supposedly essential and exclusive qualities, attributes and phenomena that are fragile, surreptitious and volatile; and a deconstruction of these "propers" opens a space in which we can begin to re-determine and re-articulate the "who" (after the subject). To quote Derrida: 56

\begin{abstract}
In order to recast, if not rigorously re-found a discourse on the 'subject,' on that which will hold the place (or replace the place) of the subject (of law, of morality, of politics...), one has to go through the experience of a deconstruction. This deconstruction (we should once again remind those who do not want to read) is neither negative nor nihilistic; it is not even a pious nihilism, as I have heard said. A concept (that is to say also an experience) of responsibility comes at this price. We have not finished paying for it. I am talking about a responsibility that is not deaf to the injunction of thought.
\end{abstract}

The concept and experience of responsibility that Derrida speaks of here have complex relations to questions of animality, time, memory, ethics, law and justice. Derrida is emphasising the responsibility and importance of thought; of "ceaselessly analysing the whole conceptual machinery, and its interestedness, which has allowed us to speak of the 'subject' up to now". 57 I read Derrida as emphasising that we need to "take responsibility" for the historical trajectory of the subject in all its complexity, for the violence embedded in its historicity, by critically engaging with the borders of the rupture between "this 'I-we' and what we call animals", 58 between the (anthropo-centric) Subject and those beings excluded from being Subject. Derrida $^{59}$ reminds us that the heterogeneous border of this rupture has a complex history, that "one can speak here of history, of a historic moment or phase, only from one of the supposed edges of the said rupture, the edge of an anthropo-centric subjectivity that is recounted or allows a history to be recounted about it, autobiographically...". I have previously illustrated that the borders that institute the subject are unstable and argued that our ethical duty towards other animals demands that we position and include the critical project located at these borders in relation to concepts of time, memory and justice. ${ }^{60} \mathrm{~A}$ genealogical reflection on the creation and reproduction of these borders not only exposes the inexactness of its constitutive functioning, but also sheds light on the hegemony of the trajectory of subjectivity and the violent spaces that various Others occupy (with)in the subjectile of the rupture and across the divide.

\footnotetext{
56 Derrida and Nancy "'Eating Well'" 107-108.

$57 \quad$ Derrida and Nancy "'Eating Well'" 109.

58 Derrida The Animal That Therefore I Am 30.

59 Derrida The Animal That Therefore I Am 31.

60 De Villiers 2012 SAJHR.
} 
Derrida's concept of carno-phallogocentrism that I previously discussed ${ }^{61}$ underlines and further complicates the violence embedded in the partitions that institute the anthropo-centric Subject and highlights another problematic of a superimposed shared subjectivity between humans and animals. I have been arguing that the Subject has been constructed on an underlying foundation of man's non-identity with juxtaposed Others, particularly women and animals. There is, however, also a constitutive scheme of ingestion that underlies the relation between subjectivity and the animal's body. Derrida's neologism "carno-phallogocentrism" captures this ingestion of the Other that is intrinsic to the founding and solidification of humanistic subjectivity and emphasises that this operation is both symbolic and real when the body or corpse of the animal is concerned:

\begin{abstract}
I would want to explain carno-phallogocentrism, even if it comes down to some sort of tautology or rather hetero-tautology as a priori synthesis, which you could translate as 'speculative idealism,' 'becoming-subject of substance,' 'absolute knowledge' passing through the 'speculative Good Friday': it suffices to take seriously the idealizing interiorisation of the phallus and the necessity of its passage through the mouth, whether it's a matter of words or of things, of sentences, of daily bread or wine, of the tongue, the lips, or the breast of the other. ${ }^{62}$
\end{abstract}

Carnophallogocentrism identifies the intentional subject (and the discourse from which he emanates) with constitutive requisites of carnivorism, masculinity and rationality. My concern is with the violence that cultivates and nourishes the borders of these requisites, both in its symbolic form of "words or sentences" and its materialising expression in the consumption of the "breast of the other". The point at issue is that the actual consumption of the animal is essential to the constitution of subjectivity, "the subject does not want just to master and possess nature actively. In our cultures, he accepts sacrifice and eats flesh". ${ }^{63}$ Man's becoming-subject derives from historical and continuing violence that extends far beyond the privative space that the animal occupies at the border of the human (subject) / animal (object) rupture. The structure of subjectivity feeds on the animal's flesh. The metaphysics of subjectivity is thus not only a conceptual violence that facilitates and legitimates our continued oppression of the animal Other, but it is fundamentally antithetical to her interests. By attempting to strategically tweak the boundaries and simply add animals into the legal construct of

\footnotetext{
61 See De Villiers 2012 SAJHR.

62 Derrida and Nancy "'Eating Well'" 113.

63 Derrida and Nancy "'Eating Well'" 114. The essential link between carnivorous sacrifice and the structure of subjectivity highlights another dimension to the deconstructive potential of veganism that I previously proposed. See De Villiers 2012 SAJHR.
} 
subjectivity in its given state we are not challenging the status quo, but rather solidifying and extending the legitimacy of a discourse and mode of social regulation that is fundamentally anthropocentric. My argument is that these theorists and activists are simply re-constructing the classical humanist subject of metaphysics and re-establishing the subject-centered system that silences the call of the animal Other. We can only address, incapacitate and move beyond this scheme of power through a rigorous deconstruction of the partitions that institute the Subject and "a reinterpretation of the whole apparatus of limits within which a history and a culture have been able to confine their criteriology". ${ }^{64}$

It is pertinent at this point to briefly revisit and highlight the ethical significance and positioning of my deconstructive project, specifically in relation to the larger themes of law and responsibility. My previous engagement with Cornell's ethical reading and renaming of deconstruction illustrates how deconstruction seen as a philosophy of limit intimates the quasitranscendental conditions constituting any system as a system and in turn exposes the inevitability of a "beyond" to a system, that which the system inescapably excludes. ${ }^{65}$ Cornell's project allows us to better understand the philosophical concept of deconstruction and her (re)conceptualisation clarifies the responsibility that deconstruction calls for in relation to a legal system. This responsibility, which Cornell ${ }^{66}$ perhaps more accurately designates as a locus of accountability, relates to our memories and the future that we promote in the act of remembrance. Derrida ${ }^{67}$ repeatedly accentuates the historical and interpretative memory fundamental to deconstruction, reminding us that "this is not only a philologico-etymological task or the historian's task but the responsibility in face of a heritage that is at the same time the heritage of an imperative or of a sheaf of injunctions". Genealogy, then, forms part of judicial integrity and the critical observer holds the tradition or system to task through the remembrance of its exclusions and partialities. ${ }^{68}$ Cornell recalls the history in which women were denied autonomy over their own bodies and, in a similar vein, I am here educing the violent sacrificial relation between subjectivity and animality. The structure of subjectivity (re)presents a very real limit to the striving for justice, specifically in its perpetuation of an anthropocentric order. Any striving for justice demands that we expose the limits of what has come to be instituted as law

\footnotetext{
$64 \quad$ Derrida "Force of Law" 247.

65 See De Villiers 2012 SAJHR.

66 Cornell Philosophy of the Limit 149.

67 Derrida "Force of Law" 248.

68 Cornell Philosophy of the Limit 149.
} 
through the preservation of the legal system. ${ }^{69}$ To quote Derrida: ${ }^{70}$

This responsibility before memory is a responsibility before the very concept of responsibility that regulates the justice and appropriateness [justesse] of our behavior, of our theoretical, practical, ethicopolitical decisions. This concept of responsibility is inseparable from a whole network of connected concepts (propriety and property, intentionality, will, freedom, conscience, consciousness, self-consciousness, subject, self, person, community, decision, and so forth). All deconstruction of this network of concepts in their given or dominant state may seem like a move toward irresponsibility at the very moment that, on the contrary, deconstruction calls for an increase in responsibility.

Deconstruction reconceived as the philosophy of the limit helps us to better understand justice as the limit to a system of positive law and the attendant increase in responsibility, precisely because it underlines the ethical aspiration behind the exposure of the system's limit and Other. Cornell's reading of deconstruction is grounded in profound insight into the limitrophe nature of deconstruction and the significance of the way in which deconstruction exposes the limit of a system or concept. The limit cannot be positively described as an oppositional cut or self-limitation and thereby reduced to a dichotomy or excess that can be incorporated into the system. The work of deconstruction is not to efface a limit, but rather to complicate the limit(s). Cornell's reading of deconstruction forcefully resonates in Derrida's ${ }^{71}$ later claim in relation to the question of the animal, that "limitrophy is therefore [his] subject. Not just because it will concern what sprouts or grows at the limit, around the limit, by maintaining the limit, but also what feeds the limit, generates it, raises it, and complicates it". It is within the complexity of limitrophy that deconstruction exposes why and how the Other is other to the system and this exposure, as Cornell reminds us, is driven by an ethical aspiration to observe the call of the Other.

The single oppositional man (subject) / animal (object) limit has not only functioned to solidify anthropocentric hegemony, but has eradicated the plethora of existences and relational structures on both sides of the rupture. Beyond the partitions that construct the human lies "a heterogeneous multiplicity of the living", complex relations of organisation that are increasingly difficult to dimidiate. ${ }^{72}$ These relations resist simple dissociation, reductive categorisation and homogenisation, rendering the conflation of the singular animal Other to a generalised occasion of "the Animal" problematic on several levels. On an ethical level, reliance on these metaphysical

\footnotetext{
69 Cornell Philosophy of the Limit 150.

70 Derrida "Force of Law" 248.

71 Derrida The Animal That Therefore I Am 29.

72 Derrida The Animal That Therefore I Am 31.
} 
categories embodies inherent violence to otherness. Recalling Cornell's ${ }^{73}$ description of the ethical relation as "the aspiration to a nonviolent relationship to the Other, and to otherness more generally, that assumes responsibility to guard the Other against the appropriation that would deny her difference and singularity", we can see how homogenisation and appropriation of "the animal" (or animal in general) betrays the most fundamental characteristic of the ethical relation. As I have also previously argued, subjectivity as building block for rights inherently relies on reductive disengagements that privilege similarity over difference and grounds ethical responsibility in likeness. ${ }^{74}$ The need for a thinking of différance rather than opposition is once again emphasised.

On an ontological level, the violent functioning of the metaphysical human / animal dualism necessitates a new non-anthropocentric perspective of singularity that resists reductive and privative accounts of being(s) and strives to embrace animals on their own terms. The genesis of such an alternative thought is, as I have already suggested, located at the border of the human / animal limit and will succeed a rigorous deconstruction of the functioning of the limit and its relation to different concepts and practices. I use the word genesis deliberately as the philosophy of the limit is not simply a disruptive and destabilising exercise that leaves us stranded before an exposed obstruction, but provides us with a space of origin and a mode of formation. It confronts us with an occasion and, more importantly, the responsibility to think (again). "There is a duty in deconstruction", reminds Derrida. ${ }^{75}$ "There has to be, if there is such a thing as duty. The subject, if subject there must be, is to come after this". ${ }^{76}$ The deconstruction of metaphysics thus opens up a space for a de novo determination of the "subject"77 that proceeds from different sites of interruption. There is indeed life following the displacement and decentring of the classical metaphysical subject and the question concerning the "who" inevitably remains.

\section{The post-deconstructive "who"}

In the same interview with Nancy, Derrida makes the following two intriguing statements towards a possible new determination or location of the who-

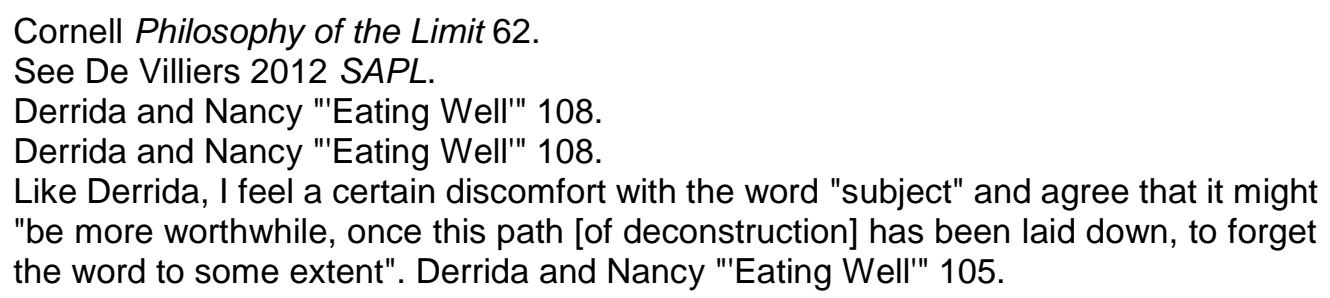


"subject":

There is another possibility that interests me more at this point: it overwhelms the question [who comes after the subject] itself, re-inscribes it in the experience of an 'affirmation,' of a 'yes' or of an 'en-gage' ... that 'yes, yes' that answers before even being able to formulate a question, that is responsible without autonomy, before and in view of all possible autonomy of the who-subject, etc. ${ }^{78}$

To be brief, I would say that it is in the relation to the 'yes' or to the Zusage presupposed in every question that one must seek a new (postdeconstructive) determination of the responsibility of the 'subject. ${ }^{.79}$

Derrida's reference to the Zusage stems from his critical reading of Heidegger in Of Spirit: Heidegger and the Question, ${ }^{80}$ in which he inter alia takes Heidegger to task for his privative account of the animal's relation to "world", as discussed above. Regarding the Zusage (promise or pledge), however, Derrida's aim is to locate a dimension of responsibility in language. Even though a comprehensive discussion of this text falls beyond the scope of this article, a brief explanation is needed to contextualise the succeeding discussion and conclusions. For Heidegger, it is clear that language has already been granted before any question is put to language. All questioning compels the preceding Zusage (pledge) of that which is being put to language and he therefore finds the primary datum of language in das Hören der Zusage (listening to the pledge of language) rather than the experience of questioning. Derrida emphasises that Heidegger thus understands the Zusage as a moment of affirmation, a "yes". ${ }^{81}$ The question is necessarily already a response to and a responsibility for that which is prior to the question and consequently "one might say that the origin of language is responsibility". ${ }^{82}$

Readers who are familiar with the work of Emmanuel Levinas will likely detect a loud echo of Levinasian ethics in Derrida's words. Levinas' project of displacing the humanist subject of classical metaphysics is already taken up in his first major work in which he critiques the Western philosophical tradition's striving for totalisation. Here Levinas ${ }^{83}$ focusses on the Other, whose "face" interrupts from a dimension of irreducible "infinity" that interrupts the "totality" of the subject's reductive existence and in doing so gives rise to the subject's inescapable ethical responsibility for the Other. The

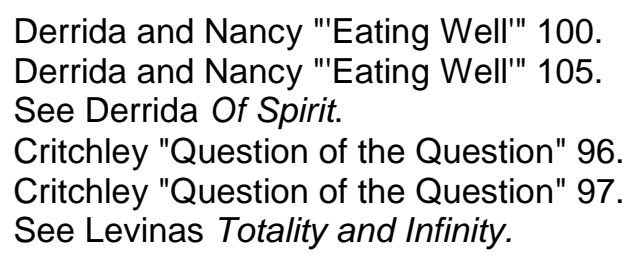


face does not present itself in the form of evidence to be seen. It breaks with the sensible by soliciting a relationship that resists expression in terms of knowledge. The alterity of the Other, which is not her individual difference but an unencompassable transcendence, remains outside comprehension. Yet despite resisting conceptualisation the face is vulnerable and against its limitless consequences expresses the commandment "Though shalt not kill". To the extent that my subjectivity is founded in and as a response to the Other's ungraspable infinity, Levinasian ethics is the experience of a call to responsibility. An attempt to comprehend and conceptualise the Being of the Other is a negation of her alterity and a rejection of this call. The Other's incomprehensible character resists relations of comprehension and synchronisation to the self and any thought of the Other thus carries within itself an excess that inevitably escapes me; "the infinite is the radically, absolutely, other" and "in thinking infinity the I from the first thinks more than it thinks" ${ }^{84}$ Levinas accordingly rejects ontology as a totalising violence that strips the Other of her radical otherness.

It is Levinas' second seminal work, however, which presents a defence of subjectivity that is written from the context of a poststructuralist critique, that bears a closer relation to Derrida's determination of the who-"subject". Indeed, there are scholars ${ }^{85}$ who conjecture that this work can be seen as a re-reading (of his first major work) that responds to Derrida's critique in "Violence and Metaphysics". 86 Derrida's critique here, in short, concerns Levinas' ineluctable reliance on the language of ontology whilst attempting to move beyond metaphysics. Whereas the point of exteriority that Levinas locates in the face of the Other is initially articulated within the constraints of ontological language, the title of Levinas' second major work, "Otherwise than Being, or, Beyond Essence", presents a dual transformative translation of the Platonic Good beyond Being and explicitly identifies the intention of his project to overcome ontology. Here Levinas portrays the radical passivity of subjectivity and primordial exposure to the Other through a distinction between the saying (le Dire) and the said (le Dit).

For Levinas, there are two dimensions of language. There is a saying or foreword that precedes language before silence is broken by verbal (or written) signs in the said. "Language does not begin with the signs that one gives, with words. Language is above all the fact of being addressed." 87 The (ethical) saying is therefore a pre-condition of the (ontological) said and I am

\footnotetext{
$84 \quad$ Levinas Collected Philosophical Papers 54.

85 Bernasconi and Critchley "Introduction" xiii.

86 Derrida "Violence and Metaphysics".

87 Levinas "Paradox of Morality" 169-170.
} 
already exposed, addressed and dedicated to the Other before I direct myself toward her. For Levinas, ${ }^{88}$ "the responsibility for another is precisely a saying prior to anything said." Very importantly, this being-for-the-Other does not stem from my decision, agreement or autonomy; my responsibility was already there before I discovered it and I am more radically constituted by this unique, infinite response-ability than my autonomy. This infinite responsibility is furthermore inescapable; whilst I may decide not to answer the Other's call that originates responsibility, I cannot silence her. I am hostage to the Other and her interruption derives from a past removed from my consciousness and will, "the core of human subjectivity is the extreme passivity of someone who always comes too late to accept his task and autonomy." 89

There is clear consonance between Levinas' interpretation of subjectivity as responsibility and Derrida's location of the who-"subject" in the "'yes, yes' that answers before even being able to formulate a question". There is, however, also critical dissonance between the two thinkers on the very question of responsibility, specifically regarding the limits of responsibility. Derrida holds that Levinasian ethics, despite displacing the self-present ego at the core of traditional humanism, ultimately remains tributary of metaphysical humanism in its reliance on anthropocentric metaphysical oppositional limits and carnophallogocentristic in its sacrificial structure. The Levinasian discourse that $a$ priori institutes the Other as man is firmly grounded in (unquestioned) metaphysical distinctions that guide an anthropocentric determination of animal Being in relation to the human. In remaining uncritically beholden to the dogmatic metaphysical axiom that allows for "a noncriminal putting to death"90 of other animals, Levinas fails to "sacrifice sacrifice"91 and remains bound to the metaphysics of subjectivity that he seeks to displace.

This dogmatic anthropocentrism of Levinas' thought betrays an internal contradiction that he is never able to resolve. When directly provoked with the question of animality, specifically regarding the possibility of the "Thou shalt not kill" commandment being expressed in the face of the animal, Levinas $^{92}$ (rather surprisingly and confusingly) grants that the animal does indeed have a face and goes on to say that "without considering animals as human beings, the ethical extends to all living beings". These statements are surprising considering the anthropocentrism that emblematises his body of

\footnotetext{
Levinas Otherwise than Being 43.

Peperzak "Presentation" 62.

Derrida and Nancy "'Eating Well"' 112.

Derrida and Nancy "'Eating Well'" 113.

Levinas "Paradox of Morality" 171-172.
} 
work and become increasingly confusing in the light of his ensuing remarks. When asked about the distinctiveness of the human face and the origin of our obligations (if any) towards animals, Levinas makes the following assertions:

\begin{abstract}
One cannot entirely refuse the face of an animal. It is via the face that one understands, for example, a dog. Yet the priority here is not found in the animal, but in the human face. We understand the animal, the face of an animal, in accordance with Dasein. The phenomenon of the face is not in its purest form in the dog. $^{93}$
\end{abstract}

We do not want to make an animal suffer needlessly and so on. But the prototype of this is human ethics. Vegetarianism, for example, arises from the transference to animals of the idea of suffering. The animal suffers. It is because we, as human, know what suffering is that we can have this obligation. ${ }^{94}$

Levinas' privileging of the human is not only problematic in its unwillingness to "sacrifice sacrifice", but also discordant with his defence of subjectivity as the direct response(ability) to a call preceding my consciousness and any form of conceptualisation that would foreshadow the "transference" of an "idea" in the said. The problematic of the animal and the ethical in Levinas'95 thought is further complicated when he states that "a more specific analysis is needed" before he can say whether a snake has a face, as if the Other is not wholly other and the face does not express an infinity that resists any appropriation within cognition. Ultimately it is clear that Levinas never rigorously considers the question of animal Being and the provocation to reflect on the place of animals in his work unearths the deeply entrenched metaphysical anthropocentrism that is dogmatically reasserted. The animal is not afforded the alterity that would place her in an asymmetrical relation to the self, her Being is deduced privatively in plurality against the measure of the human. It is this anthropocentrism to which Derrida has been very observant that leads him to claim that Levinas' thinking, like that of Heidegger, remains profoundly humanistic. I want to suggest, however, that Derrida's deconstruction of Levinas can itself be read ethically; as an intervention that directs us to the centre of the subject and aims to guard against the failure to protect the Other's otherness that Levinas' concept of the ethical relation is so attentive of. ${ }^{96}$

To this end, Derrida ${ }^{97}$ is most notably at pains to problematise the oppositional human / animal binary embedded in Western philosophical

\footnotetext{
$93 \quad$ Levinas "Paradox of Morality" 169.

Levinas "Paradox of Morality" 172.

Levinas "Paradox of Morality" 172.

Drucilla Cornell also proposes such a reading of Derrida's critique of Levinas on related themes. See Cornell Philosophy of the Limit.

97

Derrida and Nancy "'Eating Well"' 109.
} 
discourse inter alia by situating a responsibility that is irreducible to the traditional construct of the Subject, precisely by demonstrating how his disruptive motifs (différance, trace, iterability, ex-appropriation, etc.) "are at work everywhere, which is to say, well beyond humanity". Again, Derrida does not simply uncritically expand the Levinasian ethical to include other animals, but provides a framework to think through and overcome the anthropocentric milieu shaped by dominant discourses. Who, then, is the "who" in Derrida's texts and by what right, if any, should we employ this translation?

\section{Towards a non-anthropocentric refiguration}

The "who" is most importantly a singularity (rather than an individuality or atom identical to itself) "that dislocates or divides itself in gathering itself together to answer to the other, whose call somehow precedes its own identification with itself."98 This "who" is en-gaged in responsibility prior to self-presence and autonomy; overwhelmed by the trace, différance, exappropriation and signature in the affirmation of having already answered to the "yes, yes" in (in)capacity of irreplaceable singularity. The question emanating from this analytic of singularity concerns the appropriateness of its translation into a "who", a question that is particularly complex in its chronological, philosophical and grammatical topology. In continuing to address this issue, I would like to suggest that the question of "Who?" cannot and should not be separated from the deconstruction of the Subject, as if deconstruction is a singular, linear event unaffected and unrelated to the trace. We should thus guide our intervention into the problematic of the Subject by asking to what extent the question "Who?" displaces or conversely re-introduces the structure of the classical Subject.

Derrida's concern is that this thought of singularity might resist translation into the grammatical form "who", because the latter postulates inadequately examined conceptual oppositions that are fundamentally contributory to the very problem at hand and necessitate renewed and ceaseless deconstruction by and of themselves. Any post-deconstructive determination of the "Subject" should guard against positing itself in a way that is naively pre-deconstructive in the reconstitution of "an illegitimately delimited identity... in the name of a particular kind of rights". ${ }^{99}$ Deconstruction, rather, "lets itself be called by a more exacting articulation of rights" that, in a different way, prescribes more

$98 \quad$ Derrida and Nancy "'Eating Well"' 100.

$99 \quad$ Derrida and Nancy "'Eating Well"' 108-109. 
responsibility. ${ }^{100}$ The duty in deconstruction that Derrida speaks of presents itself in the form of responsibility to think again; to think radically new discourses and determinations of "subjectivity" that destabilise the problematic of the Subject from a context that it no longer controls at its centre. This might very well require that we "forget" the unforgettable word ("Subject") by no longer speaking of it, but rather writing it, "writ[ing] 'on' it as on the 'subjectile,' for example". ${ }^{101}$ This need arises because the discourse on the Subject inevitably remains expressive of its constitutive presuppositions and is destined to link subjectivity with the human, even if it predicates the disruptive force of différance, trace, inadequation etc. A further problematic inherent to the determination of the "who" as Subject relates to the call of the Other which, in order to remain singular and other, must remain un-appropriated and un-subjected. We are faced with this challenge to thought precisely because the responsibility to protect the otherness of the Other is, as Derrida ${ }^{102}$ repeatedly reminds us, not simply a theoretical directive.

The problematic of the Subject is pronounced in its translation into law and remains marked by all the constraints that I have recalled. In order to put forward the interests of animals in the legal paradigm, scholars have to communicate and structure their reasoning and claims in keeping with the categories provided by the legal system. Within the subject-centered model of law, the result is that animal rights theorists are ultimately forced to establish rights for animals as Subjects by assimilating a human-like subjectivity, thereby (re)producing a different form of anthropocentric subjectivism that simply re-establishes the borders of ethical and legal consideration at an(other) equally problematic annexation whilst naively reinforcing the anthropocentric structure they seek to destabilise and eradicate. This approach of promoting a future of animal liberation by employing the very same hegemonic constructs that have historically functioned to subjugate animals is tragically paradoxical. A deconstructive engagement with the historical functioning of animality enumerates the exclusionary limitations of and concomitant need for radically new discourses, language, politics, ethics and law. The experience of deconstruction exposes the limits of our existing legal frameworks and clears the space for a rethinking of the concept of right that can proceed without indebtedness to the interpretation of man that is being called into question. Like Derrida I do not believe in a simple "miracle of legislation" and, identifying

\footnotetext{
100 Derrida and Nancy "'Eating Well'" 109.

101 Derrida and Nancy "'Eating Well"' 105.

102 Derrida and Nancy "'Eating Well"' 111.
} 
metaphysical anthropocentrism as the critical target, I am ultimately calling for an engagement with law at a conceptual level. It is in the "beyond" to the reconsideration of the history of law and right(s) that we can allow ourselves to see and be seen by all animals looking us in the face.

\section{Bibliography}

\section{Literature}

Aristotle "Treatise on Government"

Aristotle "A Treatise on Government: Book I" in Ellis W (trans) Aristotle's Politics: A Treatise on Government (Routledge Manchester 1895) 9-35

Bernasconi and Critchley "Introduction"

Bernasconi R and Critchley S "Introduction" in Bernasconi R and Critchley S (eds) Re-reading Levinas (Indiana University Press Bloomington 1991) xixviii

Calarco 2004 Cont Philos Rev

Calarco M "Deconstruction is not Vegetarianism: Humanism, Subjectivity, and Animal Ethics" 2004 Cont Philos Rev 175-201

Calarco "Heidegger's Zoontology"

Calarco M "Heidegger's Zoontology" in Calarco M and Atterton P (eds) Animal Philosophy: Essential Readings in Continental Thought (Continuum London 2004) 18-30

Calarco Zoographies

Calarco M Zoographies: The Question of the Animal from Heidegger to Derrida (Columbia University Press New York 2008)

Cornell Philosophy of the Limit

Cornell D The Philosophy of the Limit (Routledge New York 1992)

Critchley Ethics, Politics, Subjectivity

Critchley S Ethics, Politics, Subjectivity: Essays on Derrida, Levinas and Contemporary French Thought (Verso London 1999)

Critchley "Question of the Question"

Critchley S "The Question of the Question: An Ethico-political Response to a Note in Derrida's De l'esprit' in Wood D (ed) Of Derrida, Heidegger, and Spirit (Northwestern University Press Evanston 1993) 93-102 
Derrida "Force of Law"

Derrida J "Force of Law: The 'Mystical Foundation of Authority"' (trans Quaintance M) in Anidjar G (ed) Acts of Religion (Routledge New York 2002) 230-298

Derrida Of Spirit

Derrida J Of Spirit: Heidegger and the Question (trans Bennington G and Bowlby R) (University of Chicago Press Chicago 1989)

Derrida The Animal That Therefore I Am

Derrida J The Animal That Therefore I Am (trans Wills D, ed Mallet M) (Fordham University Press New York 2008)

Derrida "Violence and Metaphysics"

Derrida J "Violence and Metaphysics: An Essay on the Thought of Emmanuel Levinas" in Writing and Difference (trans Bass A) (University of Chicago Press Chicago 1978) 79-153

Derrida and Nancy "'Eating Well'"

Derrida $J$ and Nancy $J$ "'Eating Well,' or the Calculation of the Subject: An Interview with Jacques Derrida" (trans Connor P and Ronell A) in Cadava E, Connor P and Nancy J (eds) Who Comes after the Subject? (Routledge New York 1991) 96-119

Descartes "Discourse"

Descartes R "Discourse on the Method of Rightly Conducting the Reason, and Seeking Truth in the Sciences: Part Five" in Veitch J (trans) Discourse on the Method (Cosimo Classics New York 2008) 36-46

De Villiers 2012 SAJHR

De Villiers $J$ "Towards an Ethical Relation to the Nonhuman Other: Deconstruction, Veganism and the Law" 2012 SAJHR 18-30

De Villiers 2012 SAPL

De Villiers $\mathrm{J}$ "Examining the Similarity Principle and Language of (Animal) Rights as a Foundation for Animal Liberation" 2012 SAPL 40-53

De Villiers 2015 SAPL

De Villiers J "Animal Rights Theory, Animal Welfarism and the 'New Welfarist' Amalgamation: A Critical Perspective" 2015 SAPL 406-433

Douzinas End of Human Rights

Douzinas C The End of Human Rights: Critical Legal Thought at the Turn of 
the Century (Hart Oxford 2000)

Francione Animals as Persons

Francione G Animals as Persons: Essays on the Abolition of Animal Exploitation (Columbia University Press New York 2008)

Heidegger Being and Time

Heidegger M Being and Time (trans Macquarrie $\mathrm{J}$ and Robinson E) (Harper Perennial New York 1962)

Heidegger "Letter on 'Humanism'"

Heidegger M "Letter on 'Humanism"' (trans Capuzzi F) in McNeill W (ed) Pathmarks (Cambridge University Press Cambridge 1998) 239-276

Heidegger "Plato's Doctrine of Truth"

Heidegger M "Plato's Doctrine of Truth" (trans Sheehan T) in McNeill W (ed) Pathmarks (Cambridge Universsity Press Cambridge 1998) 155-182

Heidegger "Age of the World Picture"

Heidegger M "The Age of the World Picture" in Young $\mathrm{J}$ and Haynes $\mathrm{K}$ (trans and eds) Off the Beaten Track (Cambridge University Press Cambridge 2002) 57-85

Heidegger Fundamental Concepts of Metaphysics

Heidegger M The Fundamental Concepts of Metaphysics: World, Finitude, Solitude (trans McNeill W and Walker N) (Indiana University Press Bloomington 1995)

Heidegger "Origin of the Work of Art"

Heidegger M "The Origin of the Work of Art" in Hofstadter A (trans) Poetry, Language, Thought (Harper \& Row New York 1971) 15-87

Heidegger Parmenides

Heidegger M Parmenides (trans Schuwer A and Rojcewicz R) (Indiana University Press Bloomington 1992)

Heidegger On the Way to Language

Heidegger M On the Way to Language (trans Hertz P) (Harper \& Row New York 1971)

Heidegger What is Called Thinking?

Heidegger M What is Called Thinking? (trans Gray J) (Harper \& Row New York 1968) 
Levinas Collected Philosophical Papers

Levinas E Collected Philosophical Papers (trans Lingis A) (Martinus Nijhoff Publishers Dordrecht 1987)

Levinas Otherwise than Being

Levinas E Otherwise than Being, or, Beyond Essence (trans Lingis A) (Duquesne University Press Pittsburgh 1998)

Levinas "Paradox of Morality"

Levinas E "The Paradox of Morality: An Interview with Emmanuel Levinas" (trans Benjamin A and Wright T) in Bernasconi R and Wood D (eds) The Provocation of Levinas: Rethinking the Other (Routledge New York 1988) 168-180

Levinas Totality and Infinity

Levinas E Totality and Infinity: An Essay on Exteriority (trans Lingis A) (Kluwer Academic Publishers Dordrecht 1991)

Lewis 2017 Cosmos and History

Lewis M "The Relation between Stranscendental Philosophy and Empirical Science in Heidegger's Fundamental Concepts of Metaphysics" 2017 Cosmos and History: The Journal of Natural and Social Philosophy 47-72

Peperzak "Presentation"

Peperzak A "Presentation" in Bernasconi R and Critchley S (eds) Re-Reading Levinas (Indiana University Press Bloomington 1991) 51-66

Plato "Statesman"

Plato "Statesman" (trans Rowe C) in Cooper J and Hutchinson D (eds) Plato: Complete Works (Hackett Indianapolis 1997) 294-358

Regan Defending Animal Rights

Regan T Defending Animal Rights (University of Illinois Press Urbana 2001)

Regan Case for Animal Rights

Regan T The Case for Animal Rights $2^{\text {nd }}$ ed (University of California Press Berkeley 2004)

Wise Drawing the Line

Wise S Drawing the Line: Science and the Case for Animal Rights (Perseus Books Cambridge 2002) 


\section{List of Abbreviations}

Cont Philos Rev

SAJHR

SAPL
Continental Philosophy Review

South African Journal on Human Rights

Southern African Public Law 